\title{
Utilization of Some Agro-Wastes for Cultivation of Pluerotus ostreatus (Oyster Mushroom) in Keffi Nigeria
}

\author{
Odonye Enoch Peter ${ }^{1,}$, , Galleh Raphael Peter ${ }^{1}$, Ishaya Isa Obele ${ }^{1}$, Gabriel Owuna ${ }^{1}$, \\ Makut Makwin Danladi ${ }^{1}$, Smart Obiekieze ${ }^{1}$, Ombugadu Akwashiki ${ }^{2}$ \\ ${ }^{1}$ Department of Microbiology, Faculty of Natural and Applied Sciences, Nasarawa State University, Keffi, Nigeria \\ ${ }^{2}$ Department of Zoology, Faculty of Science, Federal University Lafia, Nasarawa, Nigeria
}

\section{Email address:}

ropeodons@gmail.com (O. E. Peter)

${ }^{*}$ Corresponding author

\section{To cite this article:}

Odonye Enoch Peter, Galleh Raphael Peter, Ishaya Isa Obele, Gabriel Owuna, Makut Makwin Danladi, Smart Obiekieze, Ombugadu Akwashiki. Utilization of Some Agro-Wastes for Cultivation of Pluerotus ostreatus (Oyster Mushroom) in Keffi Nigeria. Frontiers in Environmental Microbiology. Vol. 5, No. 2, 2019, pp. 60-69. doi: 10.11648/j.fem.20190502.13

Received: April 9, 2019; Accepted: May 27, 2019; Published: July 15, 2019

\begin{abstract}
Commercial crop production and many other agro-industrial activities generate large amount of cellulose, hemicelluloses and lignin. This research is aimed at the utilization of some of these agro-wastes for the cultivation of Pleurotus ostreatus (Oyster Mushroom) in Keffi area. The agro-wastes (cassava peels (CP), banana leaves (BL), saw dust (SD), yam peels (YP) and groundnut shells (GS) were collected, sorted, shredded, sterilized and inoculated with equal proportions of Pleurotus ostreatus (P. osreatus) for a period of four weeks. Rate of mycelia growth, temperature, mycological identification, nutritional contents of $P$. osreatus harvested and microbial isolation from the spent mushroom substrates were analyzed. The numbers of days for complete ramification of the substrates by mycelia of $P$. osreatus were; 18 days for BL and GS, 24 days for $\mathrm{CP}$ and $\mathrm{YP}$ while 30 days for $\mathrm{SD}$. The room temperature within the period of exposure for fruiting of the ramified substrates ranges between $22^{\circ} \mathrm{C}$ to $28^{\circ} \mathrm{C}$ in the morning, $23^{\circ} \mathrm{C}$ to $30^{\circ} \mathrm{C}$ in the afternoon and $25^{\circ} \mathrm{C}$ to $31^{\circ} \mathrm{C}$ in the evening throughout the period of exposure. The nutritional contents of the Pleurotus ostreatus from the different substrates analysed were, Moisture content was highest in SD (87.05\%) and lest in GS (80.71\%), Protein content was highest in GS (38.13\%) and lowest in BL (16.43\%), Lipid content was highest in GS (4.62\%) and lest in CP (1.83\%), Carbohydrate content was highest in CP (78.40\%) and lest in GS (71.66\%), Fibre content was highest in BL $(9.10 \%)$ and lest in YP $(8.20 \%)$ while Ash content was highest in GS (7.37\%) and lest in YP (6.42\%). Five bacteria species (Bacillus cereus, Pseudomonas aeruginosa, Micrococcus roseus, Escherichia coli and Bacillus subtilis) and two yeast species (Candida albicans and Candida tropicalis) were isolated from the spent mushroom substrates.
\end{abstract}

Keywords: Cellulose, Hemicellulose, Lignin, Agro-waste, Pleurotus ostreatus, Inoculated, Mycelia, Mycological

\section{Introduction}

The increasing expansion of agro-industrial activity has led to the accumulation of a large quantity of lignocellulosic residues all over the world. Agricultural wastes disposal is of primary concern in today's world as they are rich in nutrient and their disposal without pretreatment can cause leaching in field, resulting in environmental pollution. To overcome this problem, cultivation of $P$. ostreatus using these agricultural wastes is the most eco-friendly and economical method to reduce the level of nutrients in these wastes to an acceptable range to be used as manure [1].

Lignocellulosic materials are the most abundant agricultural residues in the world [2] and agricultural commodities play a major role in the gross domestic products of several economies worldwide [3]. The disposal of lignocellulosic residues has often been associated with environmental pollution as well as sanitary and ecological effects [4], but several lignocellulosic residues could be useful to obtain products of great economic, energetic or nutritional value [5].

The biological breakdown of lignocellulosic materials 
depends on the hydrolytic activity of enzymes produced by variety of microbial species, especially bacteria and fungi [67]. White-rot fungi are well known for their ability to produce hydrolytic and oxidative extracellular enzymes to degrade lignocellulosic substrates [8]. The genera Pleurotus and Lentinula belong to a group of widely distributed edible mushrooms with the ability to degrade several lignocellulosic substrates $[4,8]$.

Enzymes from microorganisms, especially fungi have been indicated to be promising in degrading structural carbohydrates such as cellulose and hemicelluloses and in degrading or structurally modifying proteins and their nutritional properties [9]. Biodegradation of lignocellulosic materials can be achieved through solid state fermentation with mushrooms. With the advent of biotechnology, attempts have been made globally to make potential use of agroindustrial residues for added value by production of enzymes, organic acids, bioactive secondary metabolites and single cell protein through biodegradation [10].

Microorganisms are highly adaptive to environment and secrete both endoenzymes and exoenzymes that attack the substrate and cleave the molecular chains into segments [1112]. The secreted enzymes are proteins of complex chemical structure with high molecular weights possessing hydrophilic groups such as - $\mathrm{COOH}$,--OH, and -NH2 [13] which can attack and eventually destroy almost anything. Several factors including the availability of water, temperature, oxygen usage, minerals, $\mathrm{pH}$, redox potential, carbon and energy source influence the growth of microorganisms [12].

Since ancient times, mushrooms have been regarded as the 'food of the God'! Mushrooms have been a food supplement in various cultures and they are cultivated and eaten for their edibility and delicacy. They are considered as source of proteins, vitamins, fats, carbohydrates, amino acids and minerals [14]. Mushroom is about $16.5 \%$ dry matter out of which $7.4 \%$ is crude fibre, $14.6 \%$ is crude protein and $4.48 \%$ is fat and oil [15]. Protein contents vary between $4-9 \%$ in Auricularia species and between $24-44 \%$ in Agaricus species.

Pleurotus ostreatus can not only convert lignocellulosic waste materials into human food, but also can produce notable nutriceutical products, which have many health benefits. They provide human with an additional vegetable of high quality, and enrich the diet with high quality proteins, minerals and vitamins which can be of direct benefit to the human health and fitness. Edible mushrooms are highly nutritious and can be compared with eggs, milk and meat. The extractable bio-active compounds from medicinal mushrooms would enhance human's immune systems and improve their quality of life. The content of essential amino acids in mushroom is high and close to the need of the human body. Mushroom is also easily digestible and it has no cholesterol content [16]. The spent substrate left after harvesting the mushrooms, which is entangled with innumerable mushroom threads (collectively referred to as mycelia), can also be used as animal feed (more palatable), bio-fertilizer for soil fertility enrichment and biogas [17].
Generally, mushroom cultivation technology is very vital in the tackle against shortage of food, diminishing quality of human health and pollution of the environment, which human beings still face, and will continue to face, due to the continued increase of the world population, natural resource degradation and impacts from climate change [18].

\subsection{The Nutritional Attributes of Edible Mushrooms}

Mushrooms are considered as a delicacy all around the world. Palatability may be judged according to taste, colour, texture and flavour. Nowadays attention is paid to their pharmacological, nutritional and sensory attributes. The nutritional attributes may vary due to the genetic makeup, environment and the nature of substratum [19], [20]. Mushrooms are typically low in energy and fat content and contain remarkable amounts of vitamins, minerals, dietary fibre and protein [21]. Generally nutritional value of edible mushrooms is summarized in the Table 1 below

Table 1. General nutritional values of edible mushrooms.

\begin{tabular}{ll}
\hline Constituent & Amount [\% DW] \\
\hline Protein & $15-35$ \\
Lipids & $2-6$ \\
Carbohydrates & $50-60$ \\
Soluble fiber & $4-9$ \\
Insoluble fiber & $22-30$ \\
Mineral constituents & $5-13$ \\
\hline
\end{tabular}

Source: [19]

\subsection{Cultivation of Pleurotus ostreatus}

Pleurotus ostreatus which was initially cultivated by the Asians is now grown all over the world and is known to predominantly thrive in temperate countries such as Germany, U.S.A etc [22]. The oyster mushroom (Pleurotus ostreatus) appears to be the best candidates for production in the West African climate [23]. Mushrooms grow widely and also intensively cultivated because they are a rich source of protein [24].

Pleurotus ostreatus has been cultivated on dead tree logs to a certain extent and the attention has been shifted to the use of agricultural and industrial waste products such as cereal straws, cotton waste, saw dust, food waste, corn cobs, rice straw, wood chips, paper, cocoa pod husk, cassava peels, coffee pulp, barley, wheat straw etc [25]. Pleurotus ostreatus can actually grow on almost any substrate that was once alive [23].

Due to several reasons, cultivation of Pleurotus ostreatus alongside other traditional mushrooms has been encouraged extensively in developing countries mainly because: research into the medicinal value of mushrooms has shown that Pleurotus ostreatus and other types of mushrooms have antagonistic effect on tumour formation and also lowers blood cholesterol levels [25].

Large scale cultivation of Pleurotus ostreatus in developing countries is very essential since meat protein is an expensive commodity. This is because cultivation does not require fertilizer, pesticides and sophisticated farming 
equipment [16]. In developing countries like Nigeria, where majority of the populace are farmers, tons of agricultural wastes are burnt, discarded and neglected. Due to this, the ability of Pleurotus ostreatus to convert these agricultural wastes into enriched animal feed is therefore very useful in the prevention of environmental pollution.

Over the years various publications have made the Pleurotus ostreatus to be widely accepted and introduced into various countries in the world, especially in the tropics. In Ghana, mushroom is now being cultivated with Pleurotus ostreatus being one of the commonly grown species. Factors that affect growth of $P$. ostreatus include temperature, light, climate, moisture and carbon dioxide [16].

\subsection{Macroscopic Features of Pleurotus ostreatus}

The pileus of Pleurotus ostreatus is of oyster-shape, $40-$ $250 \mathrm{~mm}$ wide. In early stages it is spatulate to lingulate, later convex and becoming concave to flabellate. Surface is smooth. Pileus is very diverse in colour: young pileus is coloured grey lilac, violet-brown to lilac blackish and these colours can alter to cream-beige. It is margin smooth when young, later we can observe somewhat undulating and striate.

Context is white to grey-white, fleshy and radially fibrous. The odour is fungoid and it tastes mild. Lamella is long and decurrent. The edge is smooth when young, later undulating. Stipe is approximately $10-20 \times 10-25 \mathrm{~mm}$, usually lateral, rudimentary. Surface is longitudinally striate with solid context [26].

\subsection{Nutritional Properties of Pleurotus ostreatus}

The species Pleurotus ostreatus has specific flavour and aromatic properties. It is acknowledged to be rich in fiber, protein and carbohydrates. It has high amounts of minerals and vitamins while the fat content is low [5]. Cultivated species of Pleurotus ostreatus are considered as dietary food. A medium caloric value is $151 \mathrm{~J}$ in $100 \mathrm{~g}$ of edible part [27]. The content of nutritional components in wild types mushroom is similar to commercially cultivated mushrooms. However, the chemical composition of Pleurotus ostreatus may differ qualitatively and quantitatively depending on the origin, strain, extraction process and cultivation conditions [28].

Protein content in Pleurotus ostreatus varies. It differs depending on strains, differences in growing medium, substrate composition, harvest time and size of the pileus. Some essential fatty acids are present in Pleurotus species; however, not in significant amounts. It has been observed that the following lipids are present: oleic acid, linoleic acid, arachidonic acid [5].

Carbohydrates are the predominant components of the mushroom dry matter. Polysaccharides presented in Pleurotus ostreatus are represented by glycogen, dietary fiber, chitin, cellulose and hemicelluloses such as mannans, galactans and xylans.

Pleurotus ostreatus is richer in vitamin $\mathrm{B}_{1}$, vitamin $\mathrm{B}_{3}$ and folic acid in comparison with other mushroom species but the content of $\mathrm{B}_{12}$ vitamin is lower. Mineral content is strongly influenced by substratum and the pilei diameter. High contents of copper, potassium, iron, phosphorus and magnesium are stated for the pilei of Pleurotus ostreatus. However, the bioavailability of them is doubtful [27].

Various enzymes can be found in the composition of Pleurotus species. These enzymes present in Pleurotus species are rarely or never found in other organisms. Enzymatic activity varies with species and Pleurotus ostreatus is characterized with higher activity of polyphenoloxidase. This enzyme causes a rapid darkening of harvested mushrooms and reduction of their sensory and nutritive properties. It decreases their quality and their market value.

Pleurotus ostreatus mushrooms show also numerous medicinal effects due to components of some polysaccharides, lectins, polysaccharide-peptides and protein complex. Some of the described health effects are; anticarcinogenic, antioxidative, antitumor, antiviral, antibacterial, antidiabetic, antihypercholesterolic, and antiarthritic as well as eye health supporting effect [5].

\subsection{The Composting Process}

Composting has frequently been regarded as more an art than science. Composting process depends upon the feed stocks and processing conditions [29]. The biochemistry and microbiology of composting remains poorly understood to date. Despite extensive research over the past twenty years into engineering aspects and the benefits of using composts, composting is still essentially considered a 'black box' process. This stems, in part, from the inherent complexity of the composting process, which is heterogeneous in nature and is directly influenced by factors such as feedstock composition and structure, temperature, $\mathrm{pH}$, moisture, oxygen and ammonia concentrations [30].

Composting relies upon the inter-related activities of a diverse range of micro-organisms to convert organic waste substrates into a stabilized material ('compost'), which is high in humic substances ('humus') and contains useful plant nutrients. In most feedstock, the principal source of carbon and energy is derived from lignocelluloses [30]. Cellulase activities in composting materials have been widely studied and correlated to decreases in cellulose content [31]. The degradation of recalcitrant lignin in composting systems has been less well characterized, although thermophilic micro fungi, and to a lesser extent actinomycetes, are thought to play key roles [32]. Humification (the process of forming humus) is complex and thought to involve a number of degradative and condensation reactions involving lignins, carbohydrates and nitrogenous compounds [3]. Nuclear magnetic resonance spectroscopy, gas chromatography, mass spectrometry and Fourier transform infrared spectroscopy have all been used to track changes in feedstock composition and the formation of humic substances [33]. 


\subsection{Spent Mushroom Substrate}

Spent mushroom substrate (SMS) is the remnant of compost from which mushrooms have been produced and for which several important roles have been described [34]. Despite evaluation of large number of agro-industrial wastes for their use as casing material in mushroom cultivation, scant attention has been given to the importance of biological properties of the casing layer [35]. Bacteria present in casing layer considerably influence the growth and morphogenesis of mushroom production. It supports beneficial microbial populations that release growth stimulating substances, which are reportedly involved in stimulating the initiation of pin heads. Several reports are available on the beneficial effects of casing soil microbes, especially, Pseudomonas putida and Alcaligenes faecalis on Pleurotus ostreatus [36].

Not much information is available in the literature about the role of associated microflora in the casing layer and how the resident microflora in casing layer interacts with the vegetative mycelium of mushroom. There are two production-related issues requiring attention of researchers in casing soil microbiology, namely, (i) the composition of microorganisms present in casing soil and (ii) their influence on mushroom production in situ. Several methods and approaches are now available to generate information on microorganisms that reside in casing layer, which allow better assessment of microbial flora, wherein molecular tools for the identification of microorganisms are now in common use, and 16S rRNA gene analysis is intensively used in phylogenetic investigations [37-38].

\section{Materials and Methodology}

\subsection{Sample Collection}

The Pleurotus ostreatus spawns were collected from Federal Institute of Industrial Research, Oshodi, Lagos, Nigeria, while the substrates used are mainly agricultural wastes namely cassava peels, banana leaves, sawdust, yam peels, and groundnut shells, collected from different location within keffi metropolis.

\subsection{Reagents}

$70 \%$ diluted ethanol solution, Calcium carbonate $\left(\mathrm{CaCO}_{3}\right)$ lime, Calcium tetraoxosulphate vi salt $\left(\mathrm{CaSO}_{4}\right)$ gypsum.

\subsection{Identification of Pleurotus ostreatus}

The morphological features such as: primordium formation and harvest (days), coloration of the pileus at harvest (visual analysis), size of the harvested basidiocarps and handling resistance evaluated by the presence of breakable pileus (easily broken or firm) were used to identified Pleurotus ostreatus as described by [26].

\subsection{Equipments}

Autoclave, gas cylinder, polyethylene waterproof bags, wire loop, forceps, rubber ban, weighing balance, plastic bath, aluminium foil paper, masking tape, cotton wool, iron box, 2 inches plastics pipes, measuring tape, hut and wire gauge.

\subsection{Substrate Preparation}

The substrates (Cassava peels, Yam peels, banana leaves, Saw dust, and Groundnut shells) were gotten, dry, and shredded. Three (3) $\mathrm{kg}$ of each of the substrates were weighed differently and mixed with $30 \mathrm{~g}$ of $\mathrm{CaCO}_{3}$ and $20 \mathrm{~g}$ of $\mathrm{CaSO}_{4} \cdot \mathrm{CaCO}_{3}$ (lime) minimize the slippery nature that compost normally tend to have. $\mathrm{CaSO}_{4}$ (gypsum) fortify the substrates. Water was added to soak the substrates and mixed until 64\% moisture content was achieved. The wetted substrates were bagged in the polyethylene bags in triplicates, corked and wrapped with aluminium foil paper. The aluminium foil paper is to protect the polyethylene bags from melting during sterilization in the autoclave [39].

\subsection{Sterilization}

The bagged substrates in polyethylene were sterilized in autoclave for 15 minutes prior to inoculation at the temperature of $121^{\circ} \mathrm{C}$ [39].

\subsection{Inoculation of the Substrate}

Following sterilization, inoculation of ramified bottle spawns was done aseptically into the sterilized and cold bags of substrates. The spawned bags were placed in disinfected iron box, covered with the lid and placed in the hut. The hut floor was flooded with water morning and evening to keep the temperature low and the humidity high. The mycelium colonised the substrates within three weeks [17]. This is commonly referred to as the spawn run, during spawn run the mycelium grows through the substrate. The spawn run time depend on the size of the bag, amount of spawn used, the strain used and the temperature.

\subsection{Exposure for Fruiting}

The completely ramified substrates bags were moved to another disinfected iron box where they were exposed by creating little holes and covered with wire gauge. Under suitable environmental conditions (temperature, ventilation, light and humidity), primordial formation occurs and followed by the production of fruiting bodies. Humidity was kept high by constantly spraying of water [37].

\subsection{Harvesting/Packaging}

At maturity fresh mushroom were harvested from the substrate bags using hands. The fruit were harvested carefully from the bag to avoid tempering with the substrate bags so as not to predispose them to source of contamination. The harvested mushroom fruit were packaged in a transparent waterproof bag and refrigerated while some were air dried.

\subsection{Proximate Analysis and Statistical Analysis}

All the moisture, fat, ash, protein and carbohydrate content 
were determined by the guideline given by Association of Official Analytical Communities [40].

All experiments were carried out in triplicates. Data obtained were analyzed by one-way analysis of variance (ANOVA) and means were compared by Duncan's New Multiple Range test (SPSS 21.0 version). Differences were considered significant at $\mathrm{p}<0.05$.

\section{Results and Discussion}

The breakdown of polysaccharides into oligosaccharides short chains and later hydrolyzed by glycosidase into their component monomer. The metabolism of these monomers releases energy and carbon for the growth of the $P$. ostreatus as reported [41].

\subsection{Ramification of Substrates (Spawn Run)}

All the five different substrates were colonized by the Pleurotus ostreatus mycilia within a period of four (4) weeks of spawn run. The compact mass of whitish and cottony growth was formed due to complete impregnation of mycelium into the substrates. The mycelia ramification was comparatively more condensed and vigorous in Banana leaves and Groundnut shells substrates followed by Cassava peels and Yam peels substrates as compared to Sawdust. Moreover, Banana leaves and Groundnut shells substrates were heavily colonized in a short time as indicated by their incubation time (Table 2) followed by Cassava peels and Yam peels substrates whereas hyphal growth on Sawdust was quite slow and less profuse than the other substrates which were in agreement with the findings reported by [42]. The first pin heads (premodia) started appearing in all the substrates within 3-5 days after exposing the polyethylene bags to the atmosphere. The first flush (mature fruiting bodies) was harvested on Banana leaves 21 days after incubation, 22 days on Groundnut shells, 29 days on Cassava and Yam peels whereas for Sawdust 36 days after incubation which were in agreement with the findings reported by [42].

\subsection{Temperature of the Room During Pinning and Fruiting}

Pleurotus ostreatus can grow at moderate temperatures, ranging from 18 to $30^{\circ} \mathrm{C}$ [43]. [44] also recorded that the optimal temperature for both P. ostreatus and P. Cystidiosus was found to be $28^{\circ} \mathrm{C}$. Table 3 shows the hut temperatures during the period of exposure of ramified substrates bags for pinning and fruiting. The temperature ranges between $22^{\circ} \mathrm{C}$ to $30^{\circ} \mathrm{C}$ all through the period of the exposure for fruiting. The exception was on the evening of day 5 and 6 which recorded $31{ }^{\circ} \mathrm{C}$. [45] indicated that the optimal temperature for mycelium growth in oyster mushroom $P$. florida was 25 $30^{\circ} \mathrm{C}$. The Pleurotus ostreatus can be widely cultivated, and it can adapt to different temperatures. It exists on every continent except Antarctica and grows throughout the year [46].

Lower temperatures and dry condition reduced stalk height and cap size of Pleurotus ostreatus [47]. On the other hand, high temperatures in growing environment can reduce Pleurotus ostreatus development in different ideal growth tracks, allowing the development of competitive microorganisms better adapted to high temperatures [48].

\subsection{Identification of Pleurotus ostreatus}

The pileus of Pleurotus ostreatus is of oyster-shape, $40-$ $250 \mathrm{~mm}$ wide. In early stages it is spatulate to lingulate, later convex and becoming concave to flabellate. Surface is smooth. Pileus is very diverse in colour: young pileus is coloured grey lilac, violet-brown to lilac blackish and these colours was later alter to cream-beige. It is margin smooth when young, later observed as some what undulating and striate which is in line with the earlier works of [26], [42] Table 4.

\subsection{Nutritional Content of the Pleurotus ostreatus from the Different Substrates}

The various interactions of composting periods, substrates, and environmental conditions resulted in significantly different $(\mathrm{p}<0.05)$ nutritional compositions of $P$. ostreatus from this research.

The moisture content of the samples ranged from 83.68 to $87.05 \%$ (Table 5) which is within the category of high moisture foods, thus making them highly perishable [49]. High moisture contents promote susceptibility to microbial growth and enzyme activity [49]. Work of researcher [20] reported comparable values of 84 - $85 \%$ moisture content.

Protein contents ranged from 16.43 to $38.13 \%$ (Table 5). They differed significantly $(\mathrm{p}<0.05$ ) with regard to the various interactions. [20] reported that not only the protein content of the substrate but also nature of protein in the substrate influences the protein content of the fruiting bodies. Values obtained were within range of works of [50] but lower than work of $[42,49]$.

The values obtained from various substrates used for fat were in the range of 1.83 to $4.62 \%$ (Table 5). There was no significant different $(\mathrm{p}<0.05)$. This range of fat content is similar to that of earlier report of [20] and much depends on the nature of substrate. However, lower values were obtained by [51].

The carbohydrate values fell within the range of 73.94 to $78.40 \%$ (Table 5$)$. They differed significantly $(\mathrm{P}<0.05)$. The values obtained were higher than previous works of [51], [52] which recorded 65.8-66.8\% values for total carbohydrate content in different Pleurotus species.

There were appreciable quantities of fibre in the mushroom samples examined. As shown in Table 5, the fibre content of the mushrooms ranged from 8.20 to $10.0 \%$. This observation agrees with works of researchers [49] who recorded similar values. Fungi derived $\beta$-glucans are notable for their ability to modulate the immune system [20]. 
Table 2. Spawn run in Substrates.

\begin{tabular}{llllll}
\hline \multirow{2}{*}{ Days } & \multicolumn{4}{l}{ Run in substrates $(\mathbf{c m})$} & \\
\cline { 2 - 6 } & CP & BL & SD & YP & GS \\
\hline 3 & $5.0 \pm 0.50$ & $7.7 \pm 0.36$ & $8.0 \pm 1.73$ & $5.0 \pm 0.50$ & $7.0 \pm 0.50$ \\
6 & $5.5 \pm 0.46$ & $12.0 \pm 0.72$ & $9.0 \pm 1.32$ & $5.7 \pm 0.76$ & $12.5 \pm 0.65$ \\
9 & $6.6 \pm 1.37$ & $14.0 \pm 0.87$ & $9.9 \pm 0.90$ & $6.6 \pm 1.50$ & $15.7 \pm 0.89$ \\
12 & $10.6 \pm 2.82$ & $16.4 \pm 0.82$ & $11.0 \pm 0.50$ & $7.2 \pm 1.11$ & $18.1 \pm 0.47$ \\
15 & $16.5 \pm 1.26$ & $19.8 \pm 1.65$ & $12.8 \pm 0.12$ & $14.7 \pm 1.92$ & $20.5 \pm 1.18$ \\
18 & $19.0 \pm 1.82$ & $21.9 \pm 0.12$ & $13.8 \pm 0.76$ & $18.4 \pm 1.22$ & $21.8 \pm 0.15$ \\
21 & $20.6 \pm 0.72$ & \pm 0.00 & $16.6 \pm 0.87$ & $20.3 \pm 0.61$ & \\
24 & $21.7 \pm 0.15$ & & $18.3 \pm 1.13$ & $21.5 \pm 0.06$ & \\
27 & & & $20.5 \pm 0.64$ & & \\
30 & & $21.7 \pm 0.25$ & & \\
33 & & & & \\
\hline
\end{tabular}

CP: Cassava peels, BL: Banana leaves, SD: Saw dust, YP: Yam peels and GS: Groundnut shells

Table 3. Room temperature $\left({ }^{\circ} \mathrm{C}\right)$ during exposure for pining and fruiting.

\begin{tabular}{llll}
\hline Day & Morning (6 am) & Afternoon (12 noon) & Evening (6 pm) \\
\hline 1 & 28 & 30 & 30 \\
2 & 27 & 29 & 30 \\
3 & 26 & 29 & 30 \\
4 & 25 & 28 & 30 \\
5 & 27 & 29 & 31 \\
6 & 28 & 30 & 31 \\
7 & 27 & 29 & 30 \\
8 & 22 & 23 & 25 \\
9 & 27 & 29 & 30 \\
10 & 26 & 29 & 30 \\
11 & 27 & 29 & 30 \\
12 & 27 & 29 & 30 \\
13 & 27 & 29 & 30 \\
14 & 26 & 29 & 30 \\
15 & 27 & 29 & 30 \\
\hline
\end{tabular}

KEY: $\left({ }^{\circ} \mathrm{C}\right)=$ Degree Celsius

Table 4. Identification of Pleurotus ostreatus.

\begin{tabular}{ll|l}
\hline $\begin{array}{l}\text { Taxonomic } \\
\text { classification }\end{array}$ & Mycological characteristics & \\
\hline Kingdom: Fungi & Primordia stage & \\
\hline
\end{tabular}

\begin{tabular}{|c|c|c|}
\hline $\begin{array}{l}\text { Taxonomic } \\
\text { classification }\end{array}$ & Mycological characteristics & \\
\hline $\begin{array}{l}\text { Phylum: } \\
\text { Basidiomycota }\end{array}$ & & $\begin{array}{l}\text { Gills and } \\
\text { undulating striate } \\
\text { margin on } \\
\text { hymenium }\end{array}$ \\
\hline $\begin{array}{l}\text { Class: } \\
\text { Agaricomycetes }\end{array}$ & & Cap is offset \\
\hline Order: Agaricales & & $\begin{array}{l}\text { Stipe is bare }(1.0 \\
2.0 \times 1.0-2.5 \mathrm{~cm})\end{array}$ \\
\hline Family: Pleurotace & & $\begin{array}{l}\text { Ecologically } \\
\text { saprophytic }\end{array}$ \\
\hline Genus: Pleurotus & & $\begin{array}{l}\text { Basidiocap is } \\
\text { smooth, whitish }\end{array}$ \\
\hline Species: ostreatus & & \\
\hline
\end{tabular}

Table 5. Percentage Nutrient Content of Pleurotus ostreatus from the different substrates.

\begin{tabular}{lllllll}
\hline Substrates & Moi & Pro & Lip & Car & Fib & Ash \\
\hline CP & 85.21 & 22.00 & 1.83 & 78.40 & 8.44 & 6.93 \\
BL & 83.68 & 16.43 & 2.11 & 73.94 & 9.10 & 7.20 \\
SD & 87.05 & 25.08 & 3.27 & 77.93 & 8.77 & 7.33 \\
YP & 86.56 & 24.38 & 3.56 & 74.03 & 8.20 & 6.42 \\
GS & 80.71 & 38.13 & 4.62 & 71.66 & 8.80 & 7.37 \\
\hline
\end{tabular}

KEYS: Moi= Moisture content, Pro= Protein content, Lip= Lipid content, $\mathrm{Car}=$ Carbohydrate, $\mathrm{Fib}=$ Fibre, $\mathrm{Ash}=$ Ash content, $\mathrm{CP}=$ Cassava peels, $\mathrm{BL}=$ Banana leaves, $\mathrm{SD}=$ Sawdust, $\mathrm{YP}=$ Yam peels and $\mathrm{GS}=$ Groundnut shells.

Table 6. Biochemical properties of the isolates from the Spent Mushroom Substrates.

\begin{tabular}{|c|c|c|c|c|c|}
\hline & \multicolumn{5}{|c|}{ ISOLATE CODE } \\
\hline & $\mathbf{A}$ & B & $\mathrm{C}$ & D & $\mathbf{E}$ \\
\hline Gram Reaction & + & - & - & + & + \\
\hline Cellular Morphology & $\mathrm{R}$ & $\mathrm{R}$ & $\mathrm{sR}$ & $\mathrm{C}$ & $\mathrm{R}$ \\
\hline Catalase Test & + & + & + & + & + \\
\hline Oxidase Test & - & + & - & + & + \\
\hline Indole Test & - & - & + & - & - \\
\hline Methyl red Test & - & - & + & - & - \\
\hline Motility Test & + & + & + & - & + \\
\hline Starch Hydrolysis & + & - & + & - & + \\
\hline
\end{tabular}




\begin{tabular}{|c|c|c|c|c|c|}
\hline & \multicolumn{5}{|c|}{ ISOLATE CODE } \\
\hline & $\mathbf{A}$ & B & C & D & $\mathbf{E}$ \\
\hline Gelatine Hydrolysis & - & + & - & + & + \\
\hline Citrate Utilization & + & + & - & + & + \\
\hline Nitrate Reduction & + & + & + & + & + \\
\hline Glucose Fermentation & + & - & + & + & + \\
\hline Galactose Fermentation & - & + & + & - & + \\
\hline Sucrose Fermentation & - & - & + & - & + \\
\hline Lactose Fermentation & - & - & + & - & + \\
\hline Maltose Fermentation & - & - & - & + & + \\
\hline Fructose Fermentation & + & + & + & + & + \\
\hline Probable Organisms & B. cereus & P. aeruginosa & E. coli & M. roseus & B. substilis \\
\hline
\end{tabular}

KEYS; $\mathrm{R}=$ Rods, $\mathrm{sR}=$ Short rods $, \mathrm{C}=\mathrm{Cocci}, \mathrm{B}$. cereus $=$ Bacillus cereus, $\mathrm{P}$. aeruginosa $=$ Pseudomonas aeruginosa, $\mathrm{E}$. coli $=$ Escherichia coli, $\mathrm{M}$. roseus $=$ Micrococcus roseus and $\mathrm{B}$. substilis $=$ Bacillus substilis

Table 7. Biochemical activities of Yeast isolates from the Spent Mushroom Substrates.

\begin{tabular}{|c|c|c|c|c|c|c|c|c|c|c|}
\hline \multirow{2}{*}{$\begin{array}{l}\text { Isolate } \\
\text { code }\end{array}$} & \multicolumn{4}{|c|}{ Sugar fermentation } & \multicolumn{5}{|c|}{ Sugar assimilation } & \multirow{2}{*}{$\begin{array}{l}\text { Probable } \\
\text { Organisms }\end{array}$} \\
\hline & Glu & Gal & Suc & Mal & Glu & Lac & Suc & Mal & Ure & \\
\hline $\mathrm{Y}$ & + & + & - & + & + & - & + & + & - & C. albicans \\
\hline Z & + & + & + & + & + & - & + & + & - & C. tropicalis \\
\hline
\end{tabular}

Glu $=$ Glucose, $\mathrm{Gal}=$ Galactose, Suc $=$ Sucrose, Mal $=$ Maltose, Lac $=$ Lactose, Ure $=$ Urease

C. albricans $=$ Candida albicans and $\mathrm{C}$. tropicalis $=$ Candida tropicalis .

\subsection{Colonial Morphology and Biochemical Properties of Bacterial Isolated from the Spent Mushroom Substrates}

The five bacteria species isolated from the spent mushroom substrates (cassava peels, banana leaves, sawdust, yam peels and groundnut shells) used in this research were characterized as Bacillus cereus, Pseudomonas aeruginosa, Micrococcus roseus, Escherichia coli and Bacillus subtilis (Table 6). These identifications were based on series of morphological and biochemical tests as well as physiological characteristics using the standard characterization definitions of [53] and that of [54].

The endospore forming rods, Gram positive, catalase positive that readily form chains and ferment most sugars (Isolates A and E) were identified as Bacillus species [55]. A simplified classification based on morphology, endospore position, starch and gelatin hydrolysis, motility, nitrate reduction and oxidative fermentation were used to classify Isolates $\mathrm{A}$ and $\mathrm{E}$ as B. cereus and B. subtilis respectively [54]. The isolation of these bacteria from composting agricultural substrates suggests that a form of degradation had taken place. This is because [56], [39] and [53] linked these organisms with degradation of various agricultural substrates.

The isolation of Bacillus species from degrading compost is not a surprise; this is because [55] also suggested that some Bacillus and Clostridium species inhabit high temperature habitats. [57] reported that these bacteria produce spores, which are heat resistant thus making them to survive in an extremely high temperature. Similar reasons could be adduced for the presence of Micrococcus roseus since they are facultative anaerobes (Table 6).

Isolate $\mathrm{C}$ was indole positive, Gram-negative short rods that fermented lactose, maltose and fructose. Its growth on Eosine methylene blue agar to form Green metallic sheen was used to classify it as E. coli [58]. This organism, which ferments lactose and fructose (Table 6), was catalase positive and oxidase negative. The isolation of $E$. coli may be due to water source used in the sprinkling of the exposed substrates bags. The presence of $P$. aeruginosa (Isolate B) in the spent mushroom substrates may be related to its ability to survive in vast number of habitats [58].

Though fungi, bacteria and actinomycetes play unique and important roles during composting, mixed cultures of microorganisms enhance the rate of lignocellulose degradation due to their synergistic activity through utilization of intermediate degradation products [59]. Sugar fermentation and assimilation are necessary and important tests for the identification of yeast species. [60] stressed that biochemical identification is of great important for laboratory identification of Candida species. [61] and [28] concluded that Carbohydrate assimilation may be necessary for definitive identification of Candida species. Two species of yeast were isolated from cassava peels, banana leaves, sawdust, yam peels and groundnut shells spent mushroom substrates used in this research. They were coded isolate $Y$ and $\mathrm{Z}$ (Table 7). These microorganisms were characterized as Candida albicans and Candida tropicalis (Table 7).

\section{Conclusion}

The study was conducted to check the utilization of some agro-wastes for the cultivation of Pleurotus ostreatus (Mushroom) in Keffi area. Mushroom cultivation technology is very vital in the tackle against shortage of food, diminishing quality of human health and pollution of the environment, which human beings still face, and will continue to face, due to the continued increase of the world population, natural resource degradation and impacts from climate change. The inoculation of Pleurotus ostreatus on agricultural wastes will go a long way in removing large tones of these agro-wastes thereby restoring the aesthetic 
beauty of our ecosystem. All the five agro-wastes used in this study can be utilized for the cultivation of $P$. ostreatus because the substrates support the growth of the organism. In case of commercial cultivation of $P$. ostreatus, out of the five substrates banana leaves stand a better chance as seen from the study. This strategy of cleaning the ecosystem is environmentally friendly and wealth generating.

\section{References}

[1] Ritika, K. \& Ishita, T. (2017). Agricultural wastes-potential substrates for mushroom cultivation. Eur. J. Exp. Biol. 7 (5): 1-4.

[2] Shrivastava, B., Khasa, Y. P., Gupte, A., Puniya, A. K. \& Kuhad, R. C. (2011). White-rot fungal conversion of wheat straw to energy rich cattle feed. Biodegradation. 22: 823-831.

[3] Tuomela, M., Vikman, M., Hatakka, A. \& Itavaara, M. (2018). Biodegradation of lignin in a compost environment: A review. BioresourTechnol; 72 : 169-183. http://dx.doi.org/10.1016/S0960-8524(99)00104-2.

[4] Shen, Q., Dan, H., Chen, Y., \& Royse, D. J. (2015). Comparison of Oyster mushroom production practices in China and the United States. The fourth International Conference of Mushroom Biology and Mushroom products.

[5] Hernandez, D., Sanchez, J. \& Yasamaki, K. (2016). A simple procedure for preparing substrate for Pleurotus ostreatus cultivation. In Bioresource Technology [Online], vol. 90, no. 2, pp. 145-150. DOI: 10.1016/S0960-8524(03)00118-4.

[6] Sharma, R. K. \& Arora, D. S. (2010). Changes in biochemical constituents of paddy straw during degradation by white-rot fungi and its impact on in vitro digestibility. J. Appl. Microbiol. 109: 679-686.

[7] Yang, W., Guo, F., \& Wan, Z. (2017). Yield and size of oyster mushroom grown on rice/wheat straw basal substrate supplemented with cotton seed hull Saudi J. Biol. Sci., 20: 333-338 ArticlePDF (370KB).

[8] Philippoussis, A., Zervakis, G. \& Diamantopoulou, P. (2011). Bioconversion of lignocellulosic wastes through the cultivation of edible mushroom Agrocybe aegerita, Volaeriella volvacea and Pleurotus spp. World J. Microbiol. Biotech. 17: 191-200.

[9] Rai, S. N., Singh, K., Gupta, B. N. \& Lalalli, T. K. (2015). Microbial conversion of crop residues with reference to its energy utilization by ruminants. An overview in Singh, $K$ and Schiere (Eds). Bangalore, India.

[10] Pandey, A., Soccol, C. R., Nigam, P., Soccol, V. T., Vandenberghe, L. P. S. \& Mohan, R. (2013). Biotechnological potential of agro-industrial residues: II bagasse. Biores. Technol. 74: 81-87.

[11] Krishna, S. M. \& Tanu, S. (2011). Microbial biodegradation of polymeric materials. J. Biochem. Technol. 3 (2): 210-215.

[12] Huang, J. C., Shetty, A. S. \& Wang, M. S. (2015). Biodegradable plastics: A review. Advances in Polymer Technology, 10: 23-30 Kawai F.

[13] Potts, J. E. (2018). In: Critical point of planar potts model In, Encyclopedia of Chemical Technology, Wiley-Interscience, New York, 626-668 Puchner.
[14] Kholoud, M. A, Nahla,. A. B. \& Nadia, S. A. (2014). Cultivation of oyster mushroom Pleurotus ostreatus on date palm leaves mixed with other agro-wastes in Saudi Arabia. Saudi. J. Biol. Sci. 21 (6): 616-625.

[15] Oei, P. (2015). Mushroom Cultivation with Special Emphasis on Appropirate Techniques for developing countries. Tool Publications Leiden. The Netherlands.

[16] Oei, P. (2012). Mushroom cultivation, appropriate technology for mushroom growers. Leiden: Backhugs Publishers.

[17] Zenebe, G., Weldesemayat, G. \& Solomon, Z. (2016). Growth and yield performance of Pleurotus ostreatus (Jacq. Fr) Kumm (Oyster mushroom) on different substrates. Int. J. Biodiver. Curr. 6: 87.

[18] Oseni, T. O., Dube, S. S., Wahome, P. K., Masarirambi, M. T. \& Earnshaw, D. M. (2012). Effect of wheat bran supplement on growth and yield of oyster mushroom (Pleurotus ostreatus) on fermented pine sawdust substrate. ExpAgricHortic. 30-40.

[19] Velverde, M. E. Hernandez-Perez, T. \& Lopez-Parades, O. (2014). Edible Mushrooms: Improving Human Health and Promoting Quality Life. In International Journal of Microbiology [online], vol. 2015, 14 p [Reference from 5. 3. 2015]. Available on internet: $<\mathrm{http} / / /$ dx.doi.org/10.1155/2015/376387>.

[20] Saiful, M. D. I. (2015). Cultivation techniques of edible mushrooms: Agaricus bisporus, Pleurotus spp, Lentinula edodes and Volvariella volvocea. Researchgate 04. 20T06: 43: 28UTC.

[21] Cheung, P. C. K. (2010). The nutritional and health benefits of mushrooms. In Nutrition Bulletin [online], vol 35, pp. 292-299 [Reference from 3. 3. 2015]. ISSN 1467-3010. Available on internet: <http://onlinelibrary.wiley.com/doi/10.1111/j.14673010.2010.01859.x/abstract>.

[22] Tirthesh, K. S. \& Ramandra, S. (2015). Isolation, identification, and screening of cellulose degrading micro fungi from decomposed E. crassipes. Int. J. Inn. Sci. 4 (10): 509-512.

[23] Bailey, C. Gionotti, B. M. Cleaver, P. M. Cleaver, D. P. \& Holiday, J. C. (2010). Diversified agriculture part one: Simplified and lower cost methods for mushroom cultivation in Africa. Proceedings of 2nd African Conference on Edible and Medicinal Mushrooms, Accra, Ghana, March 24-28, Abstract, pg 38.

[24] Quarcoo, A. \& Adotey, G. (2013). Determination of heavy metals in Pleurotus ostreatus (oyster mushroom) and Termitomyces clypeatus (Termites mushroom) sold on selected markets in Accra, Ghana. Mycosphere 4 (5): 960-967.

[25] Subbu, L. S. (2013). Comparative studies of mycelia growth rate of Ganoderma incidum and Pleurotus flabellatus on agrowastes. Int. J. Advan. Researsh. 1 (5): 199-203.

[26] OECD. (2011). Consensus Document on the Biology of Pleurotus spp. (Oyster mushroom). [Reference from 06. 09. 15]. Available on internet: $<$ http://www.oecd.org/science/biotrack/46815828.pdf $>$.

[27] Bozdogann, A., Zeyneb, U., Bozok, F. \& Tulin, E. (2018). Antioxidant potential of Loctarius deliciosus and Pleurotus ostreatus from Amonasmountain. Int. Quart. J. Biol. Sci. 5 (3): $113-120$. 
[28] Wang, D., Sakoda, A. \& Suzuki, M. (2015). Biological efficiency and nutritional value of Pleurotus ostreatus cultivated on spent beer grain. In Bioresource Technology [online], vol. 78, no. 3, pp. 293-300 [Reference from 06. 09. 2015]. DOI: 10.1016/S0960-8524(01)00002-5.

[29] Gilbert, E. J., Riggle, D. S. \& Holland, F. D. (2013). Largescale composting-A practical Manual for the U.K. the composting association, Wellingborough, U.K.

[30] Lynch, N. J. \& Cherry, R. S. (2017). Winter composting using the passively aerated window system. Compost. Sci.; 4: 44-52. http://dx.doi.org/10.1080/1065657X.1996.10701839.

[31] Fogarty, W. M. \& Kelly, C. T. (2012). Microbial enzyme and biotechnology. Bioremediation Journal. https://books.google.com.ng/books?isbn=9400907656.

[32] Reyes-Torres, M., Ocana, R. O., Dominguez, I. \& Sanchez, A. (2018). A systematic review on the composting of green waste: Feedstock quality and optimization strategies. 77: 04037.

[33] Gonzalez, V. F. J., Almendros, C. \& Madrid, F. (2016). Molecular alteration of organic fractions from urban waste in the course of composting and their further transformation in amended soil. Sci. Total Environ; 236: 215-229. http://dx.doi.org/10.1016/S0048-9697(99)00284-3.

[34] Williams, B. C., McCullan J. T, \& Mcchay S (2012). “An initial assessment of spent mushroom compost as a potential energy feedstock," Bioresource Technology, 79 (3): 227-230.

[35] Roeland, L. B., Stefanie, I. C. K, Luis, G. L., Johan, J. P. B., Han, A. B. W. \& Peter, A. H. M. B. (2012). Effects of fluorescent Pseudomonas spp. isolated from mushroom cultures on Lecanicillium fungicola. Bioremediation Journal. 63: 210-221.

[36] Rainey P B, Cole A. L. J, Fermor T. R, \& Wood D. A (2015). "A model system for examining involvement of bacteria in basidiome initiation of Agaricus bisporus, "Mycological Research, vol. 94, pp. 191-195.

[37] Suzuki, S., Pruden, A., Marko, V. \& Zhang, T. (2017). Editorial: Antibiotic resistance in aquatic systems. Frontier. Microbiol. 8 (14): 1-3.

[38] Crossland, S., Coates, D., Grahame, J. \& Mill, P. J. (2018). Use of random amplified polymorphic DNAs (RAPDs) in separating two sibling species of Littorina. 96: 301-305.

[39] Falana, M. B., Bankole, M. O., Omemu, A. M. \& Oyewole, O. B. (2011). Microorganisms associated with supernatant solution of fermentated maize mash (Omidum) from two varieties of maize grains. J. Res. 3 (7): 1-7.

[40] AOAC (2016). Official Methods Analysis of AOAC International. 20 ${ }^{\text {th }}$ Ed., AOAC International, Gaitheerburg, Maryland, USA.

[41] Dereje F. F. (2013). Nutrient content and in vitro digestibility of cassava fractions and their potential as livestock feed. Eur. J. Agri. Sci. 11: 2668-3245.

[42] Sadh, P. K., Duhan, S. \& Singh, D. J. (2018). Agro-industrial wastes and their utilization using solid state fermentation: A review. Bioresouces \& Bioprocessing 5: 1.

[43] Mej1'a, S. J. \& Alberto', E. (2013). Heat treatment of wheat straw by immersion in hot water decreases mushroom yield in
Pleurotus ostreatus. Ver. Iberoam. Micol. 30, 125-129 (in Spanish).

[44] Hoa, H. T., \& Wang, C. (2015). The effects of temperature and nutritional conditions on mycelium growth of two oyster mushrooms (Pleurotusostreatus and Pleurotuscystidiosus). Mycobiology 43, 14-23.

[45] Neelam, S., Chennupati, S. \& Singh, S. (2013). Comparative studies on growth parameters and physio-chemical analysis of Pleurotus ostreatus and Pleurotus florida. Asian J. Plant Sci. Res. 3, 163-169.

[46] Qu, J., Huang, C. \& Zhang, J. (2016). Genome-wide functional analysis of SSR for an edible mushroom Pleurotus ostreatus. Gene 575, 524-530.

[47] Sher, H., Al-Yemeni, M., Bahkali, A. H. A. \& Sher, H. (2010). Effect of environmental factors on the yield of selected mushroom species growing in two different agro ecological zones of Pakistan. Saudi J. Biol. Sci. 17, 321-326.

[48] Ulziijargal, E., Yang, J. H., Lin, L. Y., Chen, C. P. \& Mau, J. L. (2013). Quality of bread supplemented with mushroom mycelia. FoodChem. 138, 70-76.

[49] Koutrotsios, G., Mountzouris, K. C., Chatzipavlidis, L., \& Zervakis, G. (2014). Bioconversion of lignocellulosic residues by Agrocybe cylindracea and Pleurotus ostreatus mushroom fungi: Assessment of their effect on the final product and spent substrate properties. Food Chemistry, 161, 127-136.

[50] Mamiro D. P. \& Mamiro P. S. (2011) Yield and mushroom size of Pleurotus ostreatus grown on rice straw basal substrate mixed and supplemented with various crop residues J. Anim. Plant Sci., 10, pp. 1211-1218.

[51] Singh S, Singh B, Mishra B et al. (2012). Microorganisms in Sustainable Agriculture and Biotechnology Springer Netherlands, pp 127-151.

[52] Stamets, P. (2015). Mycelium running: How mushrooms can help save the world. Berkeley, CA: Ten Speed Press.

[53] Manjunathan, J. \& Kaviyarasan, V. (2017). Bacteria associated with compost used for cultivation of Indian edible mushroom Lentinus tuber-regium (Fr). Int. J. Engr. Sci. \& Technol. 3 (1): 44-51.

[54] Bergey's Manual of Determinative Bacteriology (2012). Buchanan R. E. and Gibbons NE, eds (17th Ed.). The Williams and Wilkins Company. Baltimore.

[55] Prescott, L. M., Hawley, J. P., \& Klein, A. D., (2017). Microbiology (10th Ed.). McGraw Hill U.S.A.

[56] Okafor N, (2010). Microorganisms Associated with Cassava Fermentation for Gari Production. J. Appl. Bac. 42: 279-284.

[57] Jones D. G, (2015). Exploitation of Microorganisms (1st Ed.) Chapman and Hall. London: 248-267.

[58] Brook, D. T., Tomas, K., Brock M \& David M. W (2010). Basic Microbio with Applications. Antibiotics and other Chemotherapeutic Agents ( ${ }^{\text {rd }}$ Ed.) 114-15.

[59] Castaño, R, Borrero C \& Trillas M. L (2012). Composting Agro residues with Fungal Inoculants. BioControl, 1-12.

[60] Finegold, S. M \& Baron, E. J. (2014). Diagnostic Microbiology, $7^{\text {th }}$ ed. C. V. Mosby company St. Louis, Toronto, Princetown. 
[61] Zaini F, M. GeramiShoar, P. Kordbacheh, E. Kedmati, M. Safara \& N. Gharaeian (2013). Performance of five phenotypical methods for identification of Candida isolates from clinical materials. Iranian J. Publ. Health, 35 (1): 25-32. 